\title{
Dampak Kualitas Layanan terhadap Loyalitas dan Kepuasan Penumpang PT. Sriwijaya Airlines Kabupaten Kendari
}

Astri Yayuk Abriyani Gani

Sekolah Tinggi Manajemen Informatika dan Komputer (STMIK), Catur Sakti Kendari

Email koresponden: yayuastri88@gmail.com

\begin{abstract}
Abstrak: Penelitian ini bertujuan untuk: menganalisis pengaruh kualitas layanan terhadap kepuasan pelanggan; menganalisis pengaruh kualitas layanan terhadap kepuasan pelanggan; menganalisis pengaruh kepuasan terhadap loyalitas pelanggan; serta menganalisis pengaruh kualitas layanan terhadap loyalitas pelanggan. untuk menganalisis dampak kualitas layanan terhadap loyalitas melalui kepuasan. Objek penelitian ini adalah pelanggan PT. Sriwijaya Air Kendari. Pengumpulan data dilakukan dengan pemberian kuesioner kepada responden penelitian. Sampel penelitian sebanyak 86 responden yang ditentukan secara purposive. Analisis data dilakukan dengan analisis deskriptif dan analisis jalur yang dilakukan dengan software Smart PLS 20. Hasil penelitian menunjukkan bahwa: 1) kualitas pelayanan berpengaruh signifikan terhadap kepuasan pelanggan; 2) kualitas layanan berpengaruh signifikan terhadap loyalitas pelanggan; 3) kepuasan pelanggan berpengaruh signifikan terhadap loyalitas pelanggan; 4) kualitas pelayanan berpengaruh signifikan terhadap loyalitas melalui kepuasan.
\end{abstract}

Kata kunci: kualitas layanan; loyalitas pelanggan; kepuasan pelanggan.

Abstract: This study aimed to: 1) analyze the impact of service quality on customers' satisfaction; 2) to analyze the impact of service quality on customers' satisfaction; 3) to analyze the impact of satisfaction on customers' loyalty; 4) to analyze the impact of service quality on loyalty via satisfaction. The objects of this study were customers of PT. Sriwijaya Air Kendari. The data were gathered by administering questionnaires to the respondents of the study. The sample of the study was 86 respondents which were determined purposively. The data were then analyzed by employing a descriptive analysis and path analysis, which were executed in Smart PLS 20 software. The results of the study showed that: 1) service quality had a significant effect on customers' satisfaction; 2) service quality had a significant effect on customers' loyalty; 3) customers' satisfaction had a significant effect on customers' loyalty; 4) service quality had a significant effect on loyalty via satisfaction.

Keywords: service quality, customer's satisfaction, customer's loyalty.

\section{PENDAHULUAN}

Loyalitas pelanggan memiliki peran penting dalam sebuah perusahaan, mempertahankan pelanggan berarti meningkatkan kinerja keuangan dan 
mempertahankan kelangsungan hidup perusahaan. Hal ini menjadi alasan utama bagi sebuah perusahaan untuk menarik dan mempertahankan pelanggan. Dua hal yang menjadi pertimbangan utama perusahaan dalam mempertahankan loyalitas pelanggan adalah, pertama karena semakin mahalnya biaya perolehan pelanggan baru dalam iklim kompetisi yang sedemikian ketat, kedua adalah adanya kenyataan bahwa tingkat profitability perusahaan berbanding lurus dengan pertumbuhan antara perusahaan dan pelanggan secara permanen.

Kualitas layanan dapat mempengaruhi loyalitas pelanggan secara langsung (Zeithaml dkk., 1996) dan mempengaruhi loyalitas pelanggan secara tidak langsung melalui kepuasan (Caruana, 2002). Kualitas layanan mendorong pelanggan untuk komitmen kepada produk dan layanan suatu perusahaan sehingga berdampak kepada peningkatan market share suatu produk. Kualitas layanan sangat krusial dalam mempertahankan pelanggan dalam waktu yang lama. Perusahaan yang memiliki layanan yang superior akan dapat memaksimalkan performa keuangan perusahaan (Gilbert dkk., 2004).

Pengaruh yang terjadi antara konsep kualitas layanan terhadap loyalitas pelanggan dapat dimediasi oleh konsep kepuasan pelanggan. Bromeer, Ruyter and Peters (1999) Fillerton and Taylor (2002) dan Caruana (2002) mengemukakan bahwa pengaruh yang diberikan oleh kualitas layanan terhadap loyalitas pelanggan dapat dimediasi oleh kepuasan pelanggan. Harapan pelanggan terhadap kualitas layanan yang diberikan oleh perusahaan akan berdampak pada rasa puas atau tidak puas yang mereka terima. Jika kualitas layanan yang ditawarkan oleh perusahaan sama atau lebih besar dari harapan mereka, maka akan menyebabkan rasa puas yang diterima pelanggan dan akan berdampak pada tingkat loyalitasnya begitu

Kepuasan adalah tingkat perasaan seseorang setelah membandingkan kinerja produk (atau hasil) yang ia rasakan dengan harapannya. Jadi tingkat kepuasan merupakan fungsi dari perbedaan antara kinerja yang dirasakan (perceived performance) dan harapan (expectations) (Kotler, 2000 : 50). Selanjutnya Kottler (1997) (dalam sihombing, 2003:4) mendefinisikan kepuasan pelanggan adalah kepuasan atau kekecewaan yang dirasakan oleh konsumen setelah membandingkan antara harapan dengan kenyataan yang ada.

Zeithalm dan Bitner (2004) dan Engel et al., (1987) mengatakan bahwa kepuasan adan ketidakpuasan merupakan dampak dari hasil penilaian pelanggan atas kualitas layanan dan nilai yang tawarkan oleh perusahaan. Dari sini dapat disimpulkan bahwa penumpang yang merasa puas memiliki tendensi untuk membagi pengalamannya kepada lima hingga enam orang; sedangkan untuk pelanggan yang merasa tidak puas atau kecewa cenderung untuk menyampaikan pengalaman buruk tersebut kepada sepuluh orang lainnya.

Hasil penelitian Parasuraman (1997), Cronin et.al, (2000), Caruana et.al, (2002), Fullerton et.al, (2002), Ruyter et.al, (2000), Bloemer et.al, (1998), bahwa kualitas layanan berpengaruh signifikan dan positif terhadap kepuasan dan loyalitas pelanggan. Hal ini menunjukkan bahwa kualitas layanan merupakan salah satu faktor yang dapat membangun kepuasan dan loyalitas pelanggan. 
Artinya semakin tinggi kualitas layanan yang dirasakan pelanggan maka kepuasan semakin tinggi.

Sedangkan penelitian terdahulu yang dilakukan oleh Navaratnaseelan and Elangkumaran (2014) mengungkapan bahwa kualitas layanan tidak berpengaruh signifikan terhadap kepuasan pelanggan. Penelitian terdahulu yang dilakukan oleh Qomariah (2012) mengungkapkan bahwa kualitas layanan tidak berpengaruh signifikan terhadap kepuasan dan loyalitas. Begitupun penelitian Aprilya (2012) yang mengungkapkan bahwa kualitas layanan tidak berpengaruh signifikan terhadap kepuasan pelanggan.

Brommer, Ruyter and Peters (1999), Lee, Lee and Feick (2001), Fullerton and Taylor (2002) dan Caruana (2002) mengemukakan bahwa kepuasan pelanggan memberikan pengaruh yang signifikan terhadap loyalitas. Pelanggan yang memperoleh tingkat kepuasan setelah melakukan evaluasi terhadap pembelian produk akan berdampak pada tingkat loyalitasnya terhadap produk/jasa tersebut. Dari sini dapat disimpulkan bahwa semakin tinggi kepuasan yang diperoleh pelanggan dari hasil pembelian produk atau jasa, maka semakin tinggi tingkat loyalitasnya.

Kepuasan pelanggan harus disertai dengan loyalitas pelanggan. Kepuasan pelanggan menyangkut apa yang diungkapkan oleh penumpang tentang persepsi dan harapannya terhadap layanan yang diperoleh dari perusahaan penerbangan. Sedangkan loyalitas berkaitan dengan apa yang dilakukan penumpang setelah berinteraksi dalam suatu proses layanan perusahaan penerbangan.

Penelitian terdahulu yang dilakukan Hidayat (2009) mengungkapkan bahwa kepuasan berpengaruh signifikan terhadap loyalitas pelanggan. Sedangkan penelitian Gautama, dkk (2012) mengungkapkan bahwa kepuasan tidak berpengaruh signifikan terhadap loyalitas pelanggan.

\section{METODE PENELITIAN}

Penelitian ini merupakan penelitian kuantitatif, yang artinya data yang ditemukan disajikan dalam bentuk angka-angka kemudian diuji dengan hipotesis yang sudah disusun. Penelitian ini menggunakan Penentuan ukuran jumlah sampel dalam penelitian ini mengacu pendapat Roscoe (1975, dalam Sekaran, 2006) bahwa ukuran sampel lebih dari 30 dan kurang dari 500 adalah tepat untuk kebanyakan penelitian. Berdasarkan pendapat tersebut maka jumlah sampel penelitian ini ditetapkan secara sengaja berjumlah 86 responden. Variabel-variabel dalam penelitian ini adalah:

1. Variabel eksogen dalam penelitian ini adalah kualitas layanan penumpang pada dimensi tangibles $(\mathrm{X} 1)$, reliability $(\mathrm{X} 2)$, responsiveness $(\mathrm{X} 3)$, assurance (X4) dan Empaty (X5);

2. Variabel intervening dalam penelitian ini adalah kepuasan penumpang (Y1).

3. Variabel endogen dalam penelitian ini adalah loyalitas penumpang (Y2).

Analisis statistik deskriptif digunakan untuk mencari nilai-nilai secara terperinci tentang (frekuensi) rata-rata hitung (mean), nilai maksimum dan nilai minimim dari masing-masing variabel yang diuji dalam penelitian. Pengukuran 
data dalam penelitian ini menggunakan skala likert. Dalam pengelolaan data, skala likert termasuk data interval, Supranto (1997). Sugiono (2004) menjelaskan bahwa skala likert digunakan untuk mengukur sikap, pendapat dan persepsi seseorang atau sekelompok orang tentang fenomena sosial yang telah ditetapkan secara spesifik oleh peneliti, yang selnjutnya disebut variabel penelitian. Model yang digunakan untuk menguji pengaruh variable penelitian adalah model structural dengan menggunakan alat analisis Jalur (path analysist). Model persamaan structural merupakan metode analisis hubungan simultan variabel dependen dan independen. Tujuan analisis jalur untuk mengetahui pengaruh langsung maupun tidak langsung melalui seperangkat variabel bebas terhadap variabel terikat. Pengaruh dalam jalur tersebut di tunjukan oleh koefisien jalur pada setiap diagram jalur dari hubungan kausal antar variabel bebas terhadap variabel terikat, Riduan (2006). Untuk mengukur pengaruh langsung maupun tidak langsung dalam penelitian ini, maka data penelitian dianalisis dengan menggunakan software smartPLS. Spesifikasi model merupakan dasar di dalam menentukan hubungan antar variabel di dalam analisis jalur sebagaimana model analisis regresi berganda. Koefisien regresi dalam analisis jalur berupa koefisien parsial terstandarisasi. Koefisien regresi parsial terstandarisasi didalam analisis jalur digunakan untuk membandingkan dampak antar variabel independen terhadap variabel dependen.

\section{HASIL PENELITIAN DAN PEMBAHASAN}

\section{Hasil Penelitian}

\section{Pengujian model structural (Inner model)}

Pengujian terhadap model structural dilakukan dengan melihat nilai predictive relevance $\left(Q^{2}\right) \mathrm{Q}$-Square yang merupakan uji goodness fit model. Nilai predictive relevance $\left(Q^{2}\right)$ dihitung dengan rumus: $Q^{2}=1-\left(1-R_{1}^{2}\right)\left(1-R_{2}^{2}\right)(1-$ $\mathrm{R}^{2}{ }_{2}$ ). Adapun nilai $\mathrm{Q}$ Square pengaruh kualitas layanan terhadap loyalitas melalui kepuasan dapat disajikan melalui Tabel 1.

Tabel 1 R Square

\begin{tabular}{|c|c|}
\hline \multicolumn{1}{|c|}{ Variabel } & R-Square \\
\hline $\begin{array}{l}\text { Kepuasan } \\
\text { Loyalitas }\end{array}$ & 0,764 \\
Predictive-relevance $\left(Q^{2}\right)^{*}$ & 0,757 \\
\hline
\end{tabular}

Sumber: Hasil pengolahan data (Peneliti)

Tabel di atas menunjukan bahwa pengaruh kualitas layanan terhadap loyalitas melalui kepuasan dengan nilai Q-square sebesar 0,942 yang dapat diinterpretasikan bahwa variabilitas loyalitas dapat dijelaskan oleh kualitas layanan, kepuasan sebesar $94,2 \%$ sedangkan sisanya 5,8\% dijelaskan oleh variabel lain diluar model.

\section{Koefisien Jalur}


Kerangka hubungan kausal empiris antara $X$ dan $Y_{1}$ terhadap $Y_{2}$ dapat disajikan melalui 3 (tiga) model persamaan structural, model persamaan struktural 1 (satu) sebagai berikut:

$$
Y_{1}=\beta X Y_{1}+\varepsilon_{1}
$$

Model persamaan struktural 2 (dua) sebagai berikut :

$$
Y_{2}=\beta X Y_{2}+\beta Y_{2} Y_{1}+\varepsilon_{2}
$$

Keterangan:

$\mathrm{Y}_{2} \quad=$ loyalitas

$\mathrm{Y}_{1} \quad=$ kepuasan

$\mathrm{X}_{1}=$ kualitas layanan

$\beta_{1 \ldots .} \beta_{k}=$ koefisien jalur

$\boldsymbol{\varepsilon}_{1} \quad=$ gallat atau error 1

$\varepsilon_{2} \quad=$ gallat atau error 2

Untuk menghitung pengaruh tidak langsung kualitas layanan terhadap loyalitas melalui kepuasan, maka persamaannya sebagai berikut : $\left(\beta X Y_{1} \times \beta Y_{1} Y_{2}\right)$. Adapun nilai koefisien jalur variabel penelitian dapat disajikan pada Tabel 2.

Tabel 2 Path Coefisien

\begin{tabular}{|l|l|l|l|l|c|}
\hline & $\begin{array}{l}\text { Original } \\
\text { Sample (O) }\end{array}$ & $\begin{array}{l}\text { Sample } \\
\text { Mean (M) }\end{array}$ & $\begin{array}{l}\text { Standard } \\
\text { Deviation } \\
\text { (STDEV) }\end{array}$ & $\begin{array}{l}\text { Standard } \\
\text { Error } \\
\text { (STERR) }\end{array}$ & $\begin{array}{l}\text { T Statistics } \\
(\mid \text { O/STERR|) }\end{array}$ \\
\hline $\begin{array}{l}\text { KEPUASAN -> } \\
\text { LOYALITAS }\end{array}$ & 0,554014 & 0,526243 & 0,107122 & 0,107122 & 5,171791 \\
\hline $\begin{array}{l}\text { KUALITAS } \\
\text { LAYANAN -> } \\
\text { KEPUASAN }\end{array}$ & 0,874143 & 0,865614 & 0,052155 & 0,052155 & 16,760562 \\
\hline $\begin{array}{l}\text { KUALITAS } \\
\text { LAYANAN -> } \\
\text { LOYALITAS }\end{array}$ & 0,343448 & 0,352853 & 0,088663 & 0,088663 & 3,873635 \\
\hline
\end{tabular}

Sumber : hasil pengolahan data (peneliti)

Tabel di atas menunjukan bahwa nilai koefisien jalur kualitas layanan terhadap kepuasan sebesar 0,874. Nilai koefisien jalur kualitas layanan terhadap loyalitas sebesar 0,343. Sedangkan nilai koefisien jalur kepuasan terhadap loyalitas sebesar 0,554. Persamaan model 1 adalah sebagai berikut :

$$
Y_{1}=0,874+\varepsilon_{1}
$$

Nilai koefisien jalur kualitas layanan terhadap kepuasan sebesar 0,874. Hal ini menunjukan bahwa apabila kualitas layanan ditingkatkan maka kepuasan juga akan meningkat. Model persamaan 2 adalah sebagai berikut: 


$$
Y_{1}=0,343+0,554+\varepsilon_{1}
$$

Nilai koefisien jalur kualitas layanan terhadap loyalitas sebesar 0,343. Hal ini menunjukan bahwa apabila kualitas layanan meningkat maka loyalitas juga akan meningkat. Sedangkan koefisien jalur kepuasan terhadap loyalitas sebesar 0,554 . Hal ini menunjukan bahwa apabila kepuasan meningkat maka loyalitas juga akan meningkat. Model persamaan 3 adalah sebagai berikut:

$$
\begin{gathered}
Y_{2}=\left(\beta X Y_{1} \times \beta Y_{1} Y_{2}\right)+\varepsilon_{3} \\
(0,874 * 0,554)+\varepsilon_{3} \\
0,484 \\
\text { Maka } Y 2=0,484+\varepsilon_{3}
\end{gathered}
$$

Nilai koefisien jalur kualitas layanan terhadap loyalitas melalui kepuasan sebesar 0,484. Hal ini menunjukan bahwa apabila kepuasan menjadi variabel yang dapat memediasi kualitas layanan terhadap loyalitas.

\section{Pengujian Hipotesis}

Pengujian hipotesis dilakukan dengan uji t $(t$-test) pada masing-masing jalur pengaruh langsung secara parsial.

\section{Pengaruh kualitas Layanan terhadap Kepuasan}

Hasil pengujian pengaruh antar variabel penelitian ditunjukan oleh koefisien jalur dan t-statistik pada Tabel pah coefisien. Pada Tabel pah coefisien menunjukan bahwa nilai koefisien jalur kualitas layanan terhadap kepuasan atau $\rho_{\text {Y1X1 }}=0,874>0$ maka $\mathrm{HO}$ di tolak, Ha diterima artinya berpengaruh positif. Dengan demikian maka kualitas layanan berpengaruh positif terhadap kepuasan. Sedangkan nilai signifikansinya mengacu pada nilai t-statistik pada Tabel pah coefisien. Taraf signifikansi ditetapkan $5 \%$ atau alpha 0,05 dengan jumlah sampel sebanyak 86 responden, maka t-tabel sebesar 1,66. Pengujian hipotesis didasarkan pada membandingkan nilai t-hitung dan t-tabel. apabila t-statistic (thitung) > t-tabel $(1,66)$ maka dinyatakan berpengaruh signifikan, namun apabila nilai t-statistic (t-hitung) $<1,66$ maka tidak berpengaruh signifikan. Nilai $t$ statistik kualitas layanan terhadap loyalitas sebagaimana yang tercantum pada Tabel pah coefisien. adalah 16,76 atau 16,76>1,66 maka dinyatakan berpengaruh signifikan. Dengan demikian dapat disimpulkan bahwa kualitas layanan berpengaruh positif dan signifikan terhadap loyalitas.

\section{Pengaruh kualitas layanan terhadap loyalitas}

Tabel pah coefisien menunjukan bahwa nilai koefisien jalur kualitas layanan terhadap loyalitas atau $\rho_{\mathrm{Y} 2 \times 1}=0,343$. Oleh karena nilai $\rho_{\mathrm{Y} 2 \times 1}=0,343>0$ maka HO di tolak, Ha diterima artinya berpengaruh positif. Dengan demikian maka kualitas layanan berpengaruh positif terhadap loyalitas. Sedangkan nilai signifikansinya mengacu pada nilai t-statistik pada Tabel pah coefisien. Taraf 
signifikansi ditetapkan 5\% atau alpha 0,05 dengan jumlah sampel sejumlah 86 reponden, maka $t$-tabel sebesar 1,66 . Nilai $t$-statistik kualitas layanan terhadap loyalitas pada Tabel pah coefisien adalah 3,87 atau 3,87 > 1,66 maka dinyatakan berpengaruh signifikan. Dengan demikian dapat disimpulkan bahwa kualitas layanan berpengaruh positif dan signifikan terhadap loyalitas.

\section{Pengaruh kepuasan terhadap loyalitas}

Tabel pah coefisien menunjukan bahwa nilai koefisien jalur kepuasan terhadap loyalitas atau $\rho_{\mathrm{Y} 2 \mathrm{Y} 1}=0,554$. Oleh karena nilai $\rho_{\mathrm{Y} 2 \mathrm{Y} 1}=0,554>0$ maka HO di tolak, Ha diterima artinya berpengaruh positif. Dengan demikian maka kepuasan berpengaruh positif terhadap loyalitas. Sedangkan nilai signifikansinya mengacu pada nilai t-statistik pada Tabel pah coefisien. Taraf signifikansi ditetapkan 5\% atau alpha 0,05 dengan sampel 86 responden, maka $t$-tabel sebesar 1,66. Nilai t-statistik kepuasan terhadap loyalitas pada Tabel pah coefisien adalah 5,17 atau 5,17 > 1,66 maka dinyatakan berpengaruh signifikan. Dengan demikian dapat disimpulkan bahwa kepuasan berpengaruh positif dan signifikan terhadap loyalitas.

\section{Pengaruh kualitas layanan terhadap loyalitas melalui kepuasan}

Berdasarkan pendapat tersebut maka pengaruh kualitas layanan terhadap loyalitas melalui kepuasan yaitu : $(0.874 \times 0.554)=0.484$. Sedangkan standar error pengaruh tidak langsung adalah sebagai berikut:

$$
\begin{aligned}
\mathrm{Se}_{1} & =V \mathrm{P}_{1}{ }^{2} \cdot \mathrm{Se}_{3}{ }^{2}+\mathrm{P}_{3}{ }^{2} \cdot \mathrm{Se}_{1}{ }^{2}+\mathrm{Se}_{1}{ }^{2} . \\
\mathrm{Se}_{3}{ }^{2} & =V(0,343)^{2}(0,107)^{2}+(0,554)^{2}(0,088)^{2}+(0,088)^{2}(0,107)^{2} \\
& =\mathrm{V} 0,00134+0,00237+0,00008 \\
& =\mathrm{V} 0.003812 \\
& =0,06174
\end{aligned}
$$

Dengan demikian nilai uji t diperoleh sebagai berikut:

$$
\mathrm{t} \quad=\frac{0,484}{0,061}=7,839
$$

Nilai t sebesar 7,839 tersebut lebih besar dari 1,66 yang berarti bahwa parameter mediasi tersebut signifikan. Dengan demikian dapat disimpulkan bahwa pengaruh tidak langsung kualitas layanan terhadap loyalitas melalui kepuasan berpengaruh positif dan signifikan.

\section{Pembahasan}

\section{Pengaruh kualitas layanan terhadap kepuasan}

Berdasarkan hasil analisis pengaruh kualitas layanan terhadap kepuasan penumpang menemukan pengaruh positif dan signifikan, maka hipotesis penelitian yang menyatakan bahwa kualitas layanan berpengaruh signifikan terhadap kepuasan cukup bukti untuk diterima. Temuan ini menunjukan bahwa 
kualitas layanan PT. Sriwijaya Air mampu menjelaskan peningkatan kepuasan penumpang.

Hasil analisis deskriptif menunjukan bahwa tanggapan responden terhadap tangible, reliability, responsiveness, assurance dan emphaty, dengan skor rata-rata sebesar 3,68, skor ini dapat diinterpretasikan bahwa tanggapan responden terhadap kinerja layanan PT. Sriwijaya Air dapat dikategorikan baik. selanjutnya, hasil analisis deskriptif tanggapan responden terhadap kepuasan pelanggan dengan skor 3,62, dimana skor ini dapat diinterpretasikan bahwa tanggapan responden terhadap kepuasan atas kinerja layanan PT. Sriwijaya Air dapat dikategorikan baik. Meskipun memiliki skor dengan interpretasi baik namun kinerja layanan PT. Sriwijaya Air masih perlu ditingkatkan lagi. Oleh karena ukuran kualitas layanan pada item pernyataan (jadwal keberangkatan Sriwijaya Air selalu tepat waktu, karyawan Sriwijaya Air memilki kesigapan dalam melayani komplain penumpang, Sriwijaya Air memberikan jaminan atas pembatalan penerbangan) berada pada penilaian paling rendah dibanding item pernyataan lainnya.

Berdasarkan hasil analisis yang telah dikemukakan, maka dapat dikatakan bahwa harapan pelanggan terhadap kinerja layanan yang diberikan oleh PT. Sriwijaya Air adalah melebihi dari apa yang dipersepsikan oleh pelanggan tersebut. Dengan demikian dapat disimpulkan bahwa persepsi penumpang terhadap kualitas layanan yang diberikan oleh PT. Sriwijaya Air mempunyai pengaruh yang positif dan signifikan terhadap kepuasan penumpang.

Hasil penelitian ini mendukung pendapat Oliver (1980), Blomer (1998) Kotler \& Keller (2007) bahwa kepuasan dipengaruhi oleh kualitas layanan, artinya semakin baik kualitas layanan yang diberikan oleh perusahaan kepada pelanggan maka akan memberikan kepuasan kepada pelanggan. Pelanggan yang puas biasanya tetap setia untuk waktu yang lebih lama, membeli lagi ketika perusahaan memperkenalkan produk baru dan memperbaharui produk lama, membicarakan hal-hal baik tentang perusahaan dan produknya kepada orang lain.

Hasil penelitian ini juga mendukung pendapat Wyckof (dalam Tjiptono, 2000) bahwa kualitas layanan jasa adalah tingkat keunggulan yang diharapkan dan pengendalian atas tingkat keunggulan untuk memenuhi keinginan pelanggan. Apabila jasa yang dierima sesuai dengan yang diharapkan, maka kualitas jasa dipersepsikan baik dan memuaskan.

Hasil penelitian ini mendukung penelitian yang dilakukan oleh Aryani dan Rosinta (2010), Yusuf (2007), Caruana dan Malta (2002), Kartini (2009) yang menyatakan bahwa terdapat pengaruh yang kuat dan positif antara kualitas layanan terhadap kepuasan pelanggan, artinya bahwa semakin baik layanan yang diterima oleh pelanggan atau layanan yang diterima oleh pelanggan dapat memenuhi kebutuhan dan harapan maka pelanggan akan menggunakan jasa perusahaan lagi atau merekomendasikan jasa perusahaan kepada orang lain. 


\section{Pengaruh kualitas layanan terhadap loyalitas}

Berdasarkan hasil analisis pengaruh kualitas layanan terhadap loyalitas menemukan pengaruh positif dan signifikan, maka hipotesis penelitian yang menyatakan bahwa kualitas layanan berpengaruh signifikan terhadap loyalitas cukup bukti untuk diterima. Temuan ini menunjukan bahwa kualitas layanan PT. Sriwijaya Air mampu menjelaskan peningkatan loyalitas penumpang.

Hasil analisis deskriptif menunjukan bahwa tanggapan responden terhadap tangible, reliability, responsiveness, assurance dan emphaty, dengan skor rata-rata sebesar 3,73, skor ini dapat diinterpretasikan bahwa tanggapan responden terhadap kinerja layanan PT. Sriwijaya Air dapat dikategorikan baik. selanjutnya, hasil analisis deskriptif tanggapan responden terhadap loyalitas dengan skor 3,55, dimana skor ini dapat diinterpretasikan bahwa tanggapan responden terhadap loyalitas atas kinerja layanan PT. Sriwijaya Air dapat dikategorikan baik. Oleh karena ukuran loyalitas pada item pernyataan (kepercayaan bahwa segala keinginan penumpang akan dipenuhi oleh maskapai penerbangan, terpengaruh pada alternatif yang ditawarkan oleh maskapai penerbangan lain, merekomendasikan maskapai penerbangan kepada penumpang lain, menginformasikan pengalaman maskapai penerbangan kepada penumpang tentang kinerja maskapai penerbangan, lebih membicarakan masalah yang terjadi kepada pihak maskapai penerbangan daripada pihak maskapai penerbangan lain) berada pada penilaian paling rendah dibanding item pernyataan lainnya.

Dengan terdapatnya tanggapan yang baik terhadap kinerja layanan yang diberikan oleh PT. Sriwijaya Air dapat memberi dampak pada adanya keinginan pelanggan tersebut untuk kembali menggunakan jasa layanan karena kinerja layanan yang diberikan adalah baik. Selanjutnya dengan adanya keinginan tersebut, maka akan membentuk sikap positif pelanggan terhadap kualitas layanan yang selanjutnya akan terbentuk komitmen yang kuat dari pelanggan tersebut dan pada akhirnya akan terbentuknya loyalitas terhadap kinerja layanan.

Hasil penelitian ini mendukung pendapat Basu, (1994) yang menyatakan bahwa kualitas layanan mempunyai pengaruh secara langsung terhadap tingkat loyalitas pelanggan. Artinya bahwa semakin baik kualitas layanan yang diberikan oleh perusahaan kepada pelanggan maka pelanggan akan setia melakukan pembelian secara berulang-ulang pada perusahaan yang sama, membeli lini produk dan jasa yang ditawarkan oleh perusahaan yang sama, memberitahukan kepada orang lain kepuasan-kepuasan yang didapat dari perusahaan dan menunjukkan kekebalan terhadap tawaran dari perusahaan pesaing.

Hasil penelitian ini juga mendukung pendapat Zeithaml dkk., (1996) kualitas layanan mempengaruhi loyalitas pelanggan. Artinya kualitas layanan mendorong pelanggan untuk komitmen kepada produk dan layanan suatu perusahaan sehingga berdampak kepada peningkatan market share suatu produk.

Hasil penelitian ini juga mendukung pendapat Caruana (2002), Jamal dan Naser (2002), Yusuf (2007) yang menyatakan bahwa kualitas layanan 
memberikan pengaruh yang signifikan terhadap loyalitas pelanggan. Artinya semakin baik kualitas layanan yang diberikan kepada penumpang maka tingkat loyalitas penumpang semakin tinggi karena penumpang selalu menginginkan kesan yang baik dari perusahaan baik secara langsung maupun tidak langsung

\section{Pengaruh Kepuasan terhadap Loyalitas}

Kepuasan adalah perasaan seseorang menyangkut kenyamanan atau kekecewaan sebagai akibat dari perbandingan antara kinerja produk yang dipresepsikan dalam kaitannya dengan harapannya. Dengan demikian, kepuasan adalah perbedaan antara harapan dan kinerja yang dirasakan, yaitu penilaian antara harapan pembelian dengan kinerja yang dirasakan purna pembelian dari produk atau jasa yang bersangkutan, jika kinerja melebihi yang diharapkan maka pelanggan akan sangat puas.

Berdasarkan hasil analisis pengaruh kepuasan terhadap loyalitas menemukan pengaruh positif dan signifikan, maka hipotesis penelitian yang menyatakan bahwa kepuasan berpengaruh signifikan terhadap loyalitas cukup bukti untuk diterima. Temuan ini menunjukan bahwa kepuasan penumpang Sriwijaya Air mampu menjelaskan peningkatan loyalitas penumpang Sriwijaya Air.

Hasil analisis menunjukan bahwa dengan adanya kepuasan penumpang terhadap kinerja layanan yang diberikan oleh PT. Sriwijaya Air, maka memberi dampak pada adanya keinginan pelanggan tersebut untuk kembali menggunakan jasa layanan karena kinerja layanan yang diberikan adalah baik. selanjutnya dengan adanya keinginan tersebut, maka akan membentuk sikap positif pelanggan yang selanjutnya akan terbentuk komitmen yang kuat dari pelanggan tersebut yang diwujudkan dalam perilaku penumpang untuk menggunakan lagi jasa penerbangan Sriwijaya Air dan pada akhirnya akan terbentuk loyalitas pelanggan tersebut.

Hasil penelitian ini sejalan dengan penelitian yang dilakukan oleh Bowen dan Chen (2001), Yusuf (2007) menyatakan bahwa kepuasan pelanggan berpengaruh positif dan signifikan terhadap loyalitas pelanggan. Artinya apabila keinginan, kebutuhan dan harapan pelanggan terpenuhi, maka pelanggan akan melanjutkan pembelian merek tersebut walaupun dihadapkan pada banyak alternative merek produk pesaing. Disamping itu pelanggan akan merekomendasikan perusahaan pada orang lain dan pelanggan akan meningkatkan volume pembeliannya.

Hasil penelitian ini mendukung pendapat Gaffar dalam Sahyunu (2009) yang mengemukakan bahwa kepuasan adalah nilai yang diperoleh seseorang dari kebutuhan yang diterimanya sesuai dengan pengeluaran atas kebutuhan tersebut. Seseorang yang memperoleh kepuasan atas pelayanan yang diberikan, maka kemungkinan untuk mengulang kembali penggunaan pelayanan tersebut dapat terjadi. Dengan demikian, kepuasan yang diterima seseorang dapat menyebabkan adanya loyalitas atau penggunaan kembali jasa yang sama dimasa mendatang.

Hasil penelitian ini mendukung pendapat Caruana dan Maltha (2002) 
Kartini (2009), Kandampully \& Suhartanto (2000) yang menyatakan bahwa kepuasan pelanggan berpengaruh signifikan terhadap loyalitas pelanggan. Artinya semakin tinggi tingkat kepuasan penumpang maka semakin tinggi pula tingkat loyalitas penumpang, hal ini disebabkan oleh rasa puas atas kinerja jasa yang didapatkan dari perusahaan sehingga meningkatkan rasa loyal penumpang kepada perusahaan.

\section{Pengaruh Kualitas Layanan terhadap Loyalitas melalui Kepuasan}

Berdasarkan hasil analisis pengaruh kualitas layanan terhadap loyalitas melalui kepuasan menemukan pengaruh positif dan signifikan, maka hipotesis penelitian yang menyatakan bahwa kualitas layanan berpengaruh signifikan terhadap loyalitas melalui kepuasan cukup bukti untuk diterima. Temuan ini menunjukan bahwa kepuasan penumpang Sriwijaya Air mampu menjadi variabel yang memediasi kualitas layanan terhadap loyalitas penumpang Sriwijaya Air.

Hasil penelitian ini menunjukan bahwa kepuasan mampu menjadi variabel yang memediasi kualitas layanan terhadap loyalitas. Pengaruh secara langsung kualitas layanan terhadap loyalitas memiliki koefisien jalur sebesar 0,343 sedangkan pengaruh tidak langsung kualitas layanan terhadap loyalitas melalui kepuasan memiliki koefisien jalur sebesar 0,484. Dengan demikian maka pengaruh tidak langsung kualitas layanan terhadap loyalitas melalui kepuasan memiliki koefisien yang lebih tinggi daripada pengaruh langsung kualitas layanan terhadap loyalitas.

Hal ini menunjukan bahwa semakin baik kualitas layanan yang diberikan oleh Sriwijaya air kepada penumpang dan penumpang merasa bahwa kualitas yang diterima melebihi dari yang diharapkan maka kualitas jasa dipersepsikan baik dan memuaskan bagi penumpang Sriwijaya air. Dengan adanya kepuasan penumpang terhadap kinerja layanan yang diberikan oleh PT. Sriwijaya Air, maka memberi dampak pada adanya keinginan pelanggan tersebut untuk kembali menggunakan jasa layanan karena kinerja layanan yang diberikan adalah baik. selanjutnya dengan adanya keinginan tersebut, maka akan membentuk sikap positif pelanggan yang selanjutnya akan terbentuk komitmen yang kuat dari pelanggan tersebut yang diwujudkan dalam perilaku penumpang untuk menggunakan lagi jasa penerbangan Sriwijaya Air dan pada akhirnya akan terbentuk loyalitas pelanggan tersebut.

Hasil penelitian ini mendukung pendapat Bromeer, Ruyter and Peters (1999) Fillerton and Taylor (2002) dan Caruana (2002) mengemukakan bahwa pengaruh yang diberikan oleh kualitas layanan terhadap loyalitas pelanggan dapat dimediasi oleh kepuasan pelanggan. Harapan pelanggan terhadap kualitas layanan yang diberikan oleh perusahaan akan berdampak pada rasa puas atau tidak puas yang mereka terima. Jika kualitas layanan yang ditawarkan oleh perusahaan sama atau lebih besar dari harapan mereka, maka akan menyebabkan rasa puas yang diterima pelanggan dan akan berdampak pada tingkat loyalitasnya begitu pula sebaliknya. 


\section{Keterbatasan Penelitian}

Berdasakan hasil penelitian yang telah dikemukakan, terdapat keterbatasan dalam penelitan ini antara lain:

1. Hasil penelitian ini tidak dapat digeneralisasi untuk kasus di luar objek penelitian, karena setiap objek memiliki karakteristik yang berbeda satu dengan yang lainnya. Penelitian mendatang diharapkan dapat memperluas ruang lingkup objeknya.

2. Masih banyak variabel yang dapat mempengaruhi kepuasan dan loyalitas pelanggan selain kualitas layanan, seperti: citra, strategi, customer value, serta keungulan produk. Oleh karena itu perlu ada dukungan hasil penelitian untuk memperkuat penambahan variabel tersebut di atas.

\section{SIMPULAN}

Pengaruh Kualitas Layanan Terhadap Kepuasan dan Loyalitas Penumpang PT. Sriwijaya Airlines Distrik Kendari berupa: 1) Kualitas layanan mempunyai pengaruh yang signifikan terhadap kepuasan penumpang pada maskapai penerbangan PT. Sriwijaya Air. Hasil ini menunjukan bahwa kualitas layanan tinggi akan memberi dampak terhadap kepuasan penumpang yang tinggi pula pada PT. Sriwijaya Air; 2) Kualitas layanan mempunyai pengaruh yang signifikan terhadap loyalitas. Hasil ini menunjukan bahwa dengan kualitas layanan yang tinggi menciptakan peningkatan loyalitas penumpang pada PT. Sriwijaya Air; 3) Kepuasan penumpang mempunyai pengaruh yang signifikan terhadap loyalitas penumpang pada PT. Sriwijaya Air. Hasil ini menunjukan bahwa meningkatnya kepuasan penumpang khususnya yang disebabkan oleh kualitas layanan yang tinggi atau baik akan tercipta peningkatan loyalitas penumpang pada PT.Sriwijaya Air; 4) Kualitas layanan berpengaruh signifikan terhadap loyalitas melalui kepuasan penumpang PT. Sriwijaya Air. Hal ini menunjukan bahwa kepuasan mampu menjadi variabel yang memediasi kualitas layanan terhadap loyalitas.

\section{DAFTAR PUSTAKA}

Arbuckle, Jl and Wonthke, W. (1999). AMOS 4,01 user's guide. Chicago: Smallwater Corporation.

Baloglu, Seyhmus. (2002). Dimentions of Customer Loyalty.

Bua, Hasanuddin. (2009). Pemasaran Hubungan. Penerbit Tunggal Mandiri: Malang

Caruana, albert and malta msida, service loyalty. (2002). The effects of seevice quality and mediating role of costumer satisfaction, European journal of marketing : 2002: 36,7/8; abi/inform global.

Effendi, Rustam. (1996). Pengantar Marketing Manajement. Bagian I. Penerbit Genius Malang.

Fullerton Gordon and Taylor Shirley; Meadiating, Interactive and Non-Linear Effects in service Quality and datiasfaction With Service Researce. Canadian Journal of Administrative Sciences 19 (2), 124-136. 
Griffin Jill. (2002). Customer loyalty, How to earn it how to keep it newand revised edition, Mc Graw hill, Kentucky.

Gozali, Imam. (2004). Model Persamaan Struktural, Penerbit Universitas Diponegoro.

Hayat Yusuf. (2007). Pengaruh kualitas layanan terhadap kepuasan pelanggan, citra perusahaan dan loyalitas pelanggan pada perusahaan pada perusahaan jasa penerbangan di Sulawesi Selatan. Disertasi, Pascasarjana Universitas Brawijaya, Malang.

Kandapully Jay, Suhartanto Dwi. (2000). Custumer Loyality in the Hotel Industry: the Role of Custumer Satisfaction and Image. International Journal of Comtemporary Hotel Management Volume 12 Number 6 pp. 346-351.

Kotler, Philip, (1997). Manajemen pemasaran: analisis perencanaan implementasi dan control, terjemahan, edisi bahasa Indonesia, Jilid 2. Prenhallindo: Jakarta.

Kotler, Philip, (2000). Marketing management the mileneum edition. Printice hall inc: New Jersey.

Kotler, Philip. (1998). Manajemen Pemasaran: Analisis Perencanaan, Implementasi dan Kontrol, Terjemahan, Edisi Bahasa Indonesia, Jilid 2. Prenhallindo: Jakarta.

Kotler, Philip dan Amstrong. (2001). Manajemen Pemasaran (Terjemahan Jaka Wasana $d k k$ ). PT. Perhalindo: Jakarta.

Kotler, Philip. (2005). Manajemen Pemasaran (Terjemahan Benyamin Molan, Edisi Bahasa Indonesia Jilid 1 dan 2). PT. INDEKS Kelompok Gramedia.

Kotler and Armstrong. (2003). Dasar-Dasar Pemasaran (Terjemahan Alexander Sindoro, Edisi Bahasa Indonesia, Jilid 1). PT. INDEKS Kelompok Gramedia.

Malhotra, Naresh k. (1996). "Marketing research an applied orientation". Third edition, prentice Hall international, inc upper saddle, New Jersey.

Parasuraman A, V.A. Zeithaml and L.L. Berry. (1985). Conceptual Model of Service Quality and Implication For Future Researce journal of marketing, Vol. 49, p.41-50.

Qamari. (1998). Perilaku Konsumen dan Pelayanan Primer. Bumi Aksara: Jakarta

Rodhiah. (1997). Manajemen Pelayanan dan Pemasaran Jasa. Undip Press: Malang

Sugiyono. (2002). Metode Penelitian Administrasi. Penerbit Alfabeta: Bandung.

Sugyono. (2004). Metode Penelitian Bisnis. Alfabeta: Bandung.

Syamsuddin. (2002). Pengukuran Kepuasan Konsumen. Kansius: Yogyakarta.

Tjiptono, Fandi. (1997). Manajemen Jasa. Penerbit Andi: Yogyakarta.

Tjiptono, Fandi. (1998). Manajemen Pemasaran. Bhuanan Ilmu Populer:Jakarta

Tjiptono, Fandi. (2008). Service Management mewujudkan layanan prima. Penerbit Andy: Yogyakarta

Zeithaml A. Valarie, Parasuraman A, Berry L. Leonard. (1990). Deliviring Quality Service: Balancing, Costomer Preceptoins and Expectations, Copyright by The Free A Division Of Simon \& Schuster Inc. 1230 Avenue Of The Americas New York, NY 10020.

Zeithaml, V.A and Britner, M.J. (2004). Service Marketing: intergrating Customer 
Focus a cross the firm, $3^{\text {rd }}$ Bostom. 